
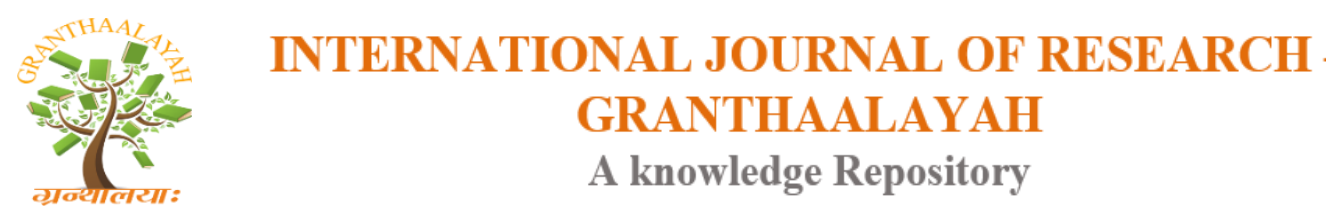

Science

\title{
INTRODUCTION OF AGRICULTURAL CROP RESIDUES AS SUPPLEMENT FOR GOATS FATTENING AMONG ANIMAL REARERS IN GIPALMA MUBI-SOUTH, ADAMAWA STATE
}

\author{
Babale.D.M 1, A. Aliyu *2, Dazala I.U 1, Wazamda.E.A 1 \\ ${ }^{1}$ Department of Animal Production, Adamawa State University, Mubi \\ ${ }^{2}$ Agricultural Economics and Extension Department, Adamawa State University, Mubi
}

\begin{abstract}
Fattening has been defined as intensive feeding of highly nutritious feed to and promotes fast growth and fat deposition to achieve desired carcass growth and quality. The main strategy is to fatten young, lean male goat to obtain either from the farmer's own flock or more often, purchased on the open market over a period of two to three months, with each farmer fattening between one and five animals. The goats are usually tethered or kept in a small sheltered enclosure at the homestead, and often fed and watered individually. Basal feeds used for goat fattening, such as hay and millet straw are supplemented with cowpea haulms, maize bran, rice bran and coconut flour which is derived from the crop residues. Poor nutrition is a major constraint in fattening small ruminants in Nigeria, this is because farmers often give the animals whatever is available, leading to waste when feed availability is high, and underfeeding when it is low (feed availability). Fattening of small ruminants as a business is very common in Nigeria. Small ruminants are usually reproduced on the farms or houses and are sold around festivities. (Christmas and Sallah) or when cash is required. No special efforts, other than grazing the animals, are made by many smallholder farmers and pastoralists to "fatten" them. A similar situation exists for fattening of large ruminants (bulls) as a business. Most farmers in Nigeria sell their bulls once they have been introduced to "fatten" these animals commercially. Goats are able to subsist and make appreciable gains in long dry season with crop residue-based diets that compare favourably with conventional concentrate rations. Some of the crop residues and by-products available are potentially good feed resources which degrade readily in the rumen, some however, have shown poor degradability and hence, require some treatments before they can contribute to animal nutrition.
\end{abstract}

Keywords: Crop Residues; Supplement; Goats Fattening Gipalma and Mubi-South.

Cite This Article: Babale.D.M, A. Aliyu, Dazala I.U, and Wazamda.E.A. (2018). "INTRODUCTION OF AGRICULTURAL CROP RESIDUES AS SUPPLEMENT FOR GOATS FATTENING AMONG ANIMAL REARERS IN GIPALMA MUBI-SOUTH, ADAMAWA STATE." International Journal of Research - Granthaalayah, 6(6), 49-66. https://doi.org/10.29121/granthaalayah.v6.i6.2018.1334. 


\section{Introduction}

\subsection{Background of the Research}

Goats account for $30 \%$ of Africa's ruminant livestock and the population goats in sub-Saharan Africa is estimated at 147 million (FAO, 2010). Sixty-four percent of the goat populations are found in the arid and semi-arid zones, sub-humid, humid and high lands (Bogoroet al., 1999). There are 102 recognized breeds of goats throughout the world with live weights ranging from 9 to $13 \mathrm{~kg}$ for small tropical breeds to over $100 \mathrm{~kg}$ for large improved dairy breeds (Dhandet al., 2003). The differences in size are in the form of the long-legged breeds to the stocky improved and short-legged West African Dwarf.

The Red Sokoto (Maradi) breeds, is the most important breed that is widely distributed in Northern Nigeria (Makunet al., 2005) and is estimated to be half of the total goats population in the country. It inhabits the sub-humid and semi-arid regions of the country. The Sahelian breed of goat is a long-legged, large breed. It is sparsely distributed along the semi-arid and arid regions of Nigeria, but most abundant in the Republic of Niger, a country bordering Nigeria to the North. They are either raised in a communal farming system or allowed to roam in search of feed (Mahanjana and Cronje, 2000).

The communal system is found in the sub-humid and Sahelian regions and Individuals own between 3-10 goats which are combined and herded as a community; this may total up to a thousand goats. Free range goat production is the predominant system. Unlike the communal farming, this system allows the goats to roam throughout the non-cropping season. In the night and during cropping season, goats are tethered in the home-stead and forage feed is cut and carried to them.

Goats in this system invariably are kept along with cropping of food and cash crops in a croplivestock production system. This system is characterized by inadequate feed, particularly during the growing season (Devendra, 1997). In Nigeria, indeed, in most African countries, goats are kept for meat, and rarely for milk. However, sometimes these goats are milked periodically and fed to children, thereby improving the protein intake of these children consequently combating malnutrition status of infants in the community (Lebbie, 2004; Makuneet al., 2005).

In Nigeria, the systems of ruminant management which is commonly known as Nomadic Fulani system or the scavenging sedentary farmers system often do not yield much. This goat production in Nigeria however characterized by low productivity levels due mainly to nutritional constrains. Grazing and browsing on natural pastures is the main source of feed in the arid and semi-arid pastoral areas, while crop residues could account up to $50 \%$ of the total quantity of fodder available which shows seasonal fluctuation. There is an acute shortage of feed supply during the dry season and the available feed during this period is of very poor quality. Poor nutrition results in low production performance, slow growth rate, loss of body condition and increased susceptibility to diseases and parasites.

In Nigeria goats are raised extensively on natural grasses and crop residues. Empirical studies have shown that grasses alone cannot provide adequate nutrients for optimum production of goats (McDonald, 1995). Crop residues are the most abundant and readily available feed resources for 
livestock production (Belete, 2006; Ajeigbeet al., 2011). Cowpea haulms, maize bran, rice bran, groundnut haulms etc are crop residues, which fed solely to the animal or supplemented with other forages as basal diet. Savadogoet al. (2000) reported that groundnut haulms and cowpea hay have high crude protein. Other agro-industrial by-products are sorghum chaff and offal that provide energy and crude fiber to the microbes in the rumen of ruminants.

Ruminant animals are important component of farming system of Northern Nigeria, where they play important and cultural roles and are flexible financial reserve for the rural population (Bamikoleet al., 2004). Sheep and goats are important sources of animal protein (meat, milk, skinand fiber) throughout the world, including developing economies.

In Adamawa State, though fattening is a profitable venture, its sustainability is not certain. Most of the fatteners are not knowledgeable as far as modern techniques in animal production are concerned. Their operations are on small scale due to inadequate of capital; feeds offered are of low quality (Jimjelet al., 2013). Fattening has been defined as intensive feeding of highly nutritious feed to promote fast growth and fat deposition to achieve desired carcass growth and quality (Alemu, 2007). Such systems can be applied to sheep as they can easily adapt to an intensive system of production under feedlots (Pasha, 2006). Fattening programs are aimed at realizing maximum growth rate and higher carcass yields in a minimum period of time, which would raise production per unit of land and the value of the livestock. This could be an economically viable strategy compared to systems where animals are kept for long periods of time on sub-optimal levels of feeding with consequent cyclic changes in weight gain. Poor nutrition is a major constraint to livestock production in sub-Saharan Africa (Osujiet al., 1993). Most ruminants in tropical Africa are raised on natural pastures which decline rapidly in quantity and quality during the dry season and such seasonal variation in nutritional status result in irregular growth and weight gain in animals (Ademosun, 1973 and Mbahiet al., 2006). To be able to reduce this irregular growth rates, crop residues and other unconventional feedstuffs are relied upon by small scale farmers (Smith et al., 1991).

Goats are able to subsist and make appreciable gains in long dry season with crop residue based diets that compare favorably with conventional concentrate rations (Malau-Aduliet al., 2003). Some of the crop residues and by-products available are potentially good feed resources which degrade readily in the rumen. Some however, have shown poor degradability and hence require some treatments before they can contribute to animal nutrition.

In the recent past, there has been a greater emphasis on sustainable meat production through backyard goat fattening which has its focus on the long-term health of the environment while maintaining the economic viability of the farm and addressing consumers' concern about mutton they eat (Fanaticoet al., 1999). Goat fattening simply refers to the preparation of the goat for marketing (Jean, 1993; Uzaet al., 1999). It is particularly attractive to poor farmers including women because of the low initial investment, rapid rate of turnover and social acceptance.

The main strategy is to fatten young, lean male goat obtained either from the farmer's own flock or, more often, purchased on the open market, over a two- to three-month period, with each farmer fattening between one and five animals. The goats are usually tethered or kept in a small sheltered enclosure at the homestead, and often fed and watered individually (Jean, 1993; Uzaet al., 1999). 
Basal feeds used for goat fattening, such as bush hay and millet straw, are commonly supplemented with cowpea hay, groundnut haulms, and millet bran which is derived from the household processing of millet grains (Uza, 1998).

The rapid growth and good condition required within a short time make feeding the appropriate quantity and quality critical for the profitability of the activity. Traditional feeds are always provided ad hoc and in an unregulated fashion.

In other words, farmers often give the animals whatever is available, leading to waste when feed availability is high, and underfeeding when feed availability is low. The result of such practice is that the growth rates in traditional goat fattening remain below the genetic potential of the animals. This combination of low growth rates and long fattening period makes traditional goat fattening largely unprofitable. Alternative feeding strategies are pertinent to make goat fattening profitable (Ayantundeet al., 2008).

The growing demands for ruminants' meats from city dwellers also present opportunities for fattening as well as improved markets for the animals. Fattening of animals is a highly profitable venture with return of premium to the farmer. Uza (1998) reported that in Nigeria, small ruminants fattening have been carried out mainly by small holder farmers while medium or big time farmers can handle on a commercial basis feedlot operations.

Goat fattening has been an established practice in Nigeria, but largely carried out by butchers and goat traders being the only category of people with the resources to buy both goats and feeds (Ayoola and Ayoade, 2006). People fatten goat for the same reason that other men operate factories, mainly to make a profit by converting raw materials which are of low value in their natural form into a product for which there is a good demand and sell for better prices (Neumann, 1977).

Crop residues and Agro-industrial By-products can play an important role in the feedings of Goat under different management systems. These cannot maintain the requirements of small ruminant and also large ruminant in Nigeria (Jarasuriya, 1985).

Agro-industrial By-products are abundant in Nigeria. The study conducted in 1985 revealed the following by-products, wheat bran/offal, cottonseeds cake, groundnut cake/pellets, palm kernel meals, molasses-fresh, brewers grains dried, brewers grain-bran, rice husk, rice chaff, cassava peels for a total quality of 60,651-tones (FAO, 1985). During the last decades, the Agro-industrial sector has grown and developed into a major sector with a total of 359 enterprises as estimated by Agro-industrial By-products registered companies in Nigeria (Reddish and Scar, 1987).

Nevertheless, new information on the quality and availability of these by-products is scarce. In addition, although many parts of the country adopted and developed techniques for incorporating these by-products in feed for livestock production, it has not yet been introduced in some parts of the country. 


\subsection{Statement of Problem}

Farmers in Gipalma did not have adequate knowledge on harnessing agricultural by-products in fattening goats. Therefore, this study was designed to demonstrate to farmers how to utilize some agricultural by-product such as maize haulms, rice bran, cowpea haulms and coconut flour in fattening of small ruminants (goats) in the study area.

\subsection{Justification of the Research}

The study was done to provide farmers with the ideas on how to formulate local feeds from the agricultural by-products and crop residues as a conventional feedstuff to reduce cost and access to available feeds for better fattening efficiency. This may serve as source of employment, income and improve household nutrition in the study area.

\subsection{Objectives of the Study}

1) To introduce the utilization of cowpea haulms, maize bran, rice bran and coconut flour for small ruminant (goat) fattening in the study area;

2) To determine the effects of the diets on growth performance of Goats in the study area;

3) To assess the level of adoption of this method of local feed formulation by farmers in the study area.

\section{Literature Review}

\subsection{Goats Domestication}

Goats are among the earliest animals to be domesticated as early as $7000 \mathrm{BC}$ and have been providing humans with milk, meat, cheese and butter, leather and manure. It is ranked among the important livestock species used for meat production around the world (Pennstate, 2000; Galal, 2005 and Olatoye, 2010). Although goats are found worldwide, they have been neglected in the livestock sector (Dubeufet al., 2004). Goats are popular with small holders because of their efficient conversion of feed into edible and high-quality meat, milk and hide (Solaiman, 2007). Moreover, goat population has increased worldwide during the last three decades and is presently estimated at approximately 840 million head (Simela and Merkel, 2008), of which 95\% are goat'smeat (Thompson, 2006). In 2005 approximately $95.8 \%$ of the total world goat population was found in developing countries: of these $43.6 \%$ were in Asia, 29.2\% in Africa, $21.7 \%$ in China and $1.3 \%$ in Central America (Olivier et al., 2005). It is estimated that there are 570 goat breeds distributed across the world, of which $89 \%$ are found in Africa.

Although goats are found in all types of ecological zones, they are concentrated in the tropics, in dry zones and in developing countries (Galal, 2005). In effect, this animal contributes substantially to the world's human food supply especially in the marginal areas of the tropics where population is on the increase (Yashimet al., 2010). Ninety-three per cent (93\%) of all goat meat and $73 \%$ of all goat milk are produced in the developing countries (FAO, 1981). Similarly, the most predominant milk is that from the cow, although, milk from goat has been accepted in most parts of the world and in developed countries as an alternative to cow milkand its contribution stands at 
$40 \%$ of the total world production of 7.2 million tons for goats in both the tropics and sub-tropics (FAO, 1982).

In Nigeria, the population of goats is about 53.8 million (FAO STAT, 2009). According to FAO (1982), Goats contribute $16.0 \%$ of the total domestically produced meat in Nigeria, which has been estimated at 813,000 tons annually. Furthermore, these ruminants produce skin that can feed the local industry. Goat skins have been estimated at 20,400 tons annually (FAO, 1982). The Maradi known for its good skin, the most widely used and distributed breed in the country is accounting for about $70 \%$ of Nigeria's goat population which has been estimated at 34.45 million Osuhoret al., (2002). The ability of Red Sokoto goat to provide milk and meat serve as a good economic return for subsistence farmers. This breed is common in the savannah zone of Nigeriathat is eight to eleven degrees north $\left(8^{\circ}-11^{\circ} N\right)$ where it constitutes more than $90 \%$ of the goat population especially in Sokoto State.

The goats are of red glossy coat color and kept mainly for their skin. The skins have been used for years to produce 'Morocco leather', one of the finest leathers in the world (Osuhoret al., 2002, and Olatoye, 2010). Goats are good producers of meat for human consumption. The animals are excellent meat producers in view of its short generation intervals and absence of religious taboos associated with their meat. Goat meat is called chevron and a rich source of protein and can help bridge the gap of malnutrition among consumers (Ozunget al., 2011).

It has been documented that goats are the principal domesticated small ruminants in terms of total numbers and production of food and fiber products (Winrock, 1983). This attribute may partly be due to the lower feed requirements compared to cattle, because of their body size (Okunlolaet al., 2010). This however, allows for easy integration of small ruminants into different farming systems (Hirpa and Abebe, 2008).

\subsection{Nigerian Breeds of Goats}

\subsubsection{Red Sokoto Goat}

The Sokoto Red, Kano Brown or Maradi goat is probably the most wide spread and well known type in Nigeria. It is the common village goat in the northern two-thirds of the country, although it is less common with transhumant pastoralists (Rim, 1993).

Red Sokoto goat is a distinctive red colored goat. The breed is well adapted to arid conditions, (Steele1996), the skins have coarse, thinly-spaced outer hairs and small sweat and wax glands and that they lacked fat Rim (1993) and grows to $25 \mathrm{~kg}$ for females and $27 \mathrm{~kg}$ for males. Both sexes have scimitar-shaped horns and males have beards.

Twinning is very common and litter size of $1.8 \mathrm{~kg}$ is the average. Milk yields of $0.5-1.0$ liters per day have been recorded on experimental stations over three month periods. According to Rim (1993), Sokoto Red goats are not heavy milkers. Giving an average yield of $3.8 \mathrm{~kg}$ per week though, the figure rises in the case of a multiple birth, or heavier doe. Nannies with twins out yield those with singles by some 20 per cent when killed for meat the carcass yield is $45-50 \%$ of live weight (Steele, 1996). 


\subsubsection{Sahel or Long Legged Goats}

They are found more abundantly in Sahel part of the country and they have varying coat color but usually mixed black, white and brown. They posses fine hair coat, short ears and long legs. Mature weight range from $25-30 \mathrm{~kg}$. The males have horns. The breed is well adapted to nomadic and wide range grazing. They are meat animals although they could be used for milk and skin production (Rim, 1993).

\subsubsection{West African Dwarf (WAD) Goats}

They are found mainly in the forest belt of Southern Nigeria. The breed is hardy and trypano tolerant. According to Steele (1996), they have small body sizes and strongly set short legs. The breed is black or white or a combination of all the three colors. They are highly prolific giving birth to twins and triplets. Mature weight is $20-25 \mathrm{~kg}$ mainly used for meat but also has dairy potentials.

\subsection{Nutrient Requirement of Goat}

Efficient utilization of nutrients depends on an adequate supply of energy, which is of paramount importance in determining the productivity of goats (Schoenian, 2009). Nutrients are substances that aid in the support of life for the animals. The total digestible nutrient (TDN) is a measure of energy and quality of feeds requirements for low quality forages contain in 40-55\% TDN, and concentrate feeds contain from 70-90\%TDN (Luginbuhl and Poore, 1998). In addition, nutrition exerts a very large influence on flock reproduction, such as milk, meat, skin production and kid growth. Nutrition level largely determines growth rate in ruminants. Ruminants with higher growth potential have higher nutritional needs, especially with regards to protein. Small ruminants require energy, protein, vitamins, minerals, fiber, and water. Energy (calories) is usually the most limiting nutrient, whereas protein is the most expensive (Poore, 1998). Deficiencies, excesses, and imbalances of vitamins and minerals can limit animal performance and lead to various health problems. Fiber (bulk) is necessary to maintain rumen environment and prevent digestive upsets. Water is the cheapest feed ingredient, yet often the most neglected (Schoenian, 2009).

\subsection{Energy Requirement}

The energy requirements of goats needed for maintenance (including physical activity), optimum growth, reproduction, milk and fiber production; for various categories of goats are expressed as digestible energy (DE), metabolizable energy ME, and net energy (NE), for maintenance, weight gain, pregnancy, lactation, and fiber production (NRC, 2011). Similarly, the energy requirements for maintenance of goats have been derived from pooled means of experimental data reported in terms of $\mathrm{kcl} \mathrm{ME} / \mathrm{W}_{\mathrm{kg}}{ }^{0.75}$ per day. The mean value of $101.38 \mathrm{kcal} \mathrm{ME} / \mathrm{W}_{\mathrm{kg}}{ }^{0.75}$ has been used to determine goat maintenance requirements for body weights ranging from 10-100kg. The energy requirements have also been expressed as they vary with energy concentration in diet from 2.0-2.4 $\mathrm{M}$ cal $\mathrm{ME} / \mathrm{kg} \mathrm{DM}$. in addition to the maintenance requirement, requirements for activity, pregnancy, growth, lactation, and fiber production must be considered (Merck and Dohme, 2011). 


\subsection{Protein Requirement}

Proteins are the major constituents of the animal body and are continuously needed in the feed for cell repair and synthetic processes. The transformation of feed protein into body protein is an important process of nutrition and metabolism. Proteins consist of amino acids and are building blocks of all body cells. Protein deficiencies in the diet deplete stores in the blood, liver, and muscles and predispose animals to a variety of serious and even fatal ailments. Below a minimum level of $6 \%$ crude protein (CP) in the diet, feed intake will be reduced, which leads a combined deficiency of energy and protein (NRC, 2011). Two types of biologically determined protein requirements have been reported. They pertain to a minimum and maintenance levels, which must not be confused. The minimum protein requirements for goats have been reported by five authors and the mean value is $1.42 \mathrm{~g}$ DP or $2.03 \mathrm{~g}$ TP/ $\mathrm{W}_{\mathrm{kg}}{ }^{0.75}(70 \%$ average digestibility of total feed protein was found in these studies) (NRC, 2011). Protein is required for most normal functions of the body, including maintenance, growth, reproduction; lactation and hair production. Protein deficiencies in the diet deplete stores in the blood, liver, and muscles and predispose animals to a variety of serious and even fatal ailments. Food intake and dietary digestibility are reduced if dietary protein is less than $6 \%$, further compounding an energy protein deficiency (Merck and Dohme, 2011).

Moreover, average meat goats require about 10-14\% crude protein and 60-65\% TDN (on a dry matter basis) in the total diet. Pasture, forbs, and browse are usually the primary and most economical source of nutrients for goats. Goats are generally considered a browse-consuming species and they have the unique ability to select plants when they are at their most nutritious state (Lemus and Brown, 2008). A good rule of thumb would be to change feed no faster than $10 \%$ per day. Production of milk requires more protein than would be needed for body maintenance. Thus, a milking doe is fed ration of at least $16 \%$ protein, while a dry mature doe or buck will do well on $12 \%$. Protein is expensive and any excess is just wasted (Khan, 2003).

\subsection{Mineral Requirements}

Requirements of minerals have not been established definitively for goats at either maintenance or production levels. However, some classical studies in mineral metabolism have been conducted with goats as an experimental subject. With these, more recent studies support assumptions that some mineral requirements in goats are similar to those in other ruminant species like sheep (NRC, 2011).

In addition to the elements in organic matter (oxygen, nitrogen, carbon and hydrogen), seven major and nine minor minerals are considered dietary essentials for livestock. The major minerals that must be fed in relatively large amount are calcium, phosphorus, sodium, chlorine, magnesium, potassium and Sulphur. Minor or trace minerals, required in small amount include, iron, iodine, copper, molybdenum, zinc, manganese, cobalt, selenium and fluorine. Others which are possibly essential at extremely low levels are chromium, nickel, and vanadium, silicon, tin and arsenic. Most these essential or possibly essential elements occur naturally in feedstuffs at levels that do not constitute problems in nutrition. However, situations often exist when one or more minerals, especially the major ones, are sufficiently low to reduce productivity. Trace minerals in particular 
can be present in toxic amount. Proper balance of minerals and bioavailability from supplements are more important than actual levels (NRC, 2011).

\subsection{Water Requirement}

Water is obviously important for goats, and the amount required depends on that needed for the maintenance of normal water balance and to provide for satisfactory levels of production. The normal body water content of the goat varies with age, amount of fat in the body and environmental temperatures. It would be expected to exceed $60 \%$ of the body weight and $75 \%$ of the non-bony tissues. Water requirements may be met by free water consumption, but other important sources include water contained in the feed ingested and metabolic water resulting from oxidation of energy sources.

Major water losses include those from urine, lactation, evaporation and perspiration (NRC, 2011). Goats should be provided unlimited access to fresh, clean water. Goats are among the most efficient of domestic animals in their use of water, approaching the camel in their low rate of water turnover per unit of body weight. Goats appear to be less subject to high temperature stress than other species of domestic livestock. In addition to a lesser need for body water evaporation for maintaining comfort in hot climates, they can conserve body losses of water by decreasing losses in urine and feces. Factors affecting water intake in goats include lactation, environmental temperature, and water content of forage consumed, amount of exercise and salt and mineral content of diet (Merck and Dohme, 2011).

\subsection{Vitamin Requirement}

Vitamins are group of compounds essential for normal body processes. Typical range or pasture diets of goats should contain adequate levels of vitamins or vitamin precursors to maintain normal health of the animal. The dietary vitamin requirement is relatively simple because of the nature of the feeds they ordinarily consumed and the synthesis of vitamin in the rumen (Gimene, 1994 and NRC, 2011). Pen-fed animals goats held on restricted diets, and high- producing animals may need a supplemental vitamin supply (NRC, 2011).

Vitamins are needed by the body in very small quantities. The vitamins most likely to be deficient in the diet are vitamin A and D. all vitamins B and $\mathrm{K}$ are formed by bacteria found in the rumen of goat and are not considered dietetically essential. Vitamin $\mathrm{C}$ is synthesized in the body tissues in adequate quantities to meet needs (Luginbuhl and poor, 1998). Suggestions as to the vitamin requirements of goats are more sparse. At best, almost all vitamin recommendations for goats must be based on those for sheep (Merck and Dohme, 2011).

\subsubsection{Vitamin A}

Vitamin A is involved in many areas of the body metabolism, and as a result deficiency signs are varied. Experimental evidences of vitamin A deficiencies include keratinization of the epithelia of the respiratory, alimentary, and reproductive and urinary tracts, and of the eye. Signs include multiple infections, poor bone development, and birth of abnormal offspring, and vision impairment night blindness, the ability to see under poorly lighted conditions, is the classic 
deficiency in goats include; loss of appetite, loss of weight, unthrifty appearance, night blindness, and a thick nasal discharge (Schoenian, 2009). Vitamin A is not contained in forages, but its precursors are common in plants and are usually present in proportion to plant pigments. Vitamin $\mathrm{A}$ is stored in the liver fat of animals during times when intake exceeds requirements. During periods of low carotene supplies in the diet, this stored vitamin A can be mobilized and utilized without signs of a vitamin A deficiency. Typical goat diets contain adequate carotene to prevent vitamin A deficiency. The tendency of the goat to search out palatable green plant parts ensures it an advantage over other ruminant species. Vitamin A deficiency in goats in the tropics is rare except under period of lack (NRC, 2011).

\subsubsection{Vitamin D}

Vitamin D is essential for the absorption and metabolism of calcium and phosphorus. In its absence, or at low levels, normal bone development is impaired. Soft, irregular shaped leg and rib bones resulting from a vitamin D deficiency are signs of "rickets" (NRC, 2011). Thus, vitamin D has been referred to as the anthracitic factor. A form of rickets can also be seen in the newborn of an adult female deficient during pregnancy. Otherwise, deficiencies in adult animals are considered rare. Vitamin D is available to animals both through the diet and as a result of exposure to sunlight. Ultraviolet radiation from sunlight acts on ergo sterol, a plant sterol and on 7 dehydrocholesterol, a sterol of animal origin, to produce compounds having anthracitic activity (vitamin D2 and D3, respectively). Thus, sun-cured hays are excellent sources of vitamin D. Animals exposed to sunlight can obtain some of their requirement directly from radiation of 7dehydrocholesterol in their skin, and the activation of vitamin D3 occurs in the liver and kidney of animals (Merck and Dhome, 2011).

Vitamin D deficiency is unlikely under normal grazing conditions, although a form of osteodystrophia has been produced experimentally in goats. Vitamin D should be supplied to growing animals that are denied sunlight over extended periods because of cloud or confinement to housing (NRC, 2011).

\subsubsection{Vitamin $E$}

According to Merck, (2011), Vitamin E deficiency in sheep is commonly associated with white muscle disease, also called stiff lamb disease. This malady is seen in young nursing lambs and will improve with vitamin E therapy. An association selenium deficiency will intensify the disease. Vitamin E is alleged to improve reproductive deficiency, but dietary supplementation experiments have not produced consistent results. Evidence of spontaneous vitamin E deficiency signs in goats is lacking. It is suggested that the probability of lowered productivity in goats as a resultof a vitamin $\mathrm{E}$ deficiency is remote. However, vitamin $\mathrm{E}$ transferred to milk is considered important because of the anti oxidation properties that aid in milk storage (NRC, 2011).

\subsubsection{Vitamin $K$}

Vitamin K (the blood clotting vitamin), is plentiful in a variety of feedstuffs and in addition, is readily synthesized in the rumen. A deficiency is unlikely (NRC, 2011). 


\subsection{Dry Matter Intake of Goats}

Dry matter (DM) is the amount of feed remaining when all the water has been removed from it. It is used as a guide to determine how much fresh or moist feed can be fed. A $30 \mathrm{~kg}$ goat requires; for maintenance $1.6 \% \mathrm{DM}$ as per cent of live weight $=0.9 \mathrm{~kg}, 1.4 \mathrm{~kg}$ if DM of feed is $25 \%$, four times as much is needed to achieve a set target figure. It is used as a guide to determine how much fresh or moist feed can be fed (Khan, 2003).

Dry matter intake (DMI) varies from $35-80 \mathrm{~g} / \mathrm{kg}$ metabolic body size for different Indian breed of goat with a $70 \mathrm{~kg}$ as average (3.2\% of body weight). The DMI of the smaller breed (Barbari and Black Bengala) is higher than the larger breed (Jamunapari, Beetal). Dry matter intake (DMI) varies according to the density of the diet and the physical character of the roughage. DMI in growing kids (pre-ruminant and early growth) ranges between $35-50 \mathrm{~g} / \mathrm{kg}$ metabolic body size where as in lactating Jamunapari goat ranges from 120-140g DMI of goat is higher in comparison to larger farm animals. Meat goats have $3 \%$ of body weight and dairy goats have $4-6 \%$ of body weight (Reddy, 2007).

\subsection{Efficiency of Feed Utilization}

Efficiency of feed utilization is simply the reciprocal of Feed Conversion Ratio (FCR) and since feed is the denominator, it should be maximized. The important point to remember is that more efficient cattle will have a lower FCR and a higher efficiency of feed utilization. When comparing efficiency from different studies, farms or calculations it is important to not only be clear about which terms is being used, but to be also clear about the measures (units) of inputs and outputs used (Morris, 2006).

\section{Materials and Methods}

\subsection{Study Area}

The study area is situated in Mubi South Local Government area of Adamawa state lying between latitude 10-18 'North and longitude 13-39'East', (Adebayo, 2004). The local Government shares common boundaries with Mubi north local Government to the west, Michika local Government to the North, Hong local Government to the South and Cameroun Republic to the east, with a population of 128,937 people according to 2006 population census in Nigeria (CBN 2007), this population is made up of several ethnic groups, among which are Gude, Fali, Njanyi and Fulani. These heterogeneous ethnic groups have been coexisting peacefully and they play greater attention to agriculture and trade.

Farming is the major occupation of the people of the area with cowpea and maize as the most cultivated crops. Other crops cultivated include soybeans, rice, and sorghum. However, the people also engage in some activities like rearing of animals, fishing, hunting, and trading. The vegetation is guinea savannah with tall grasses and short scattered trees. It has hilly and mountainous terrain. The hill has a general height of about 800-1500 meters above sea level. The dominant drainage system in Mubi North Local Government is the river Yedzaram which take its source from Gella 
Hills that flows through the region toward South North direction (Field research, 2017). The materials used include; weighing balance, bucket, rake, feeder, shovel, sticks, ropes and ribbons.

\subsection{Experimental Animal and Management}

A total of three (3) weaned Red Sokoto Goats with average weight of $11.65 \mathrm{Kg}$ were used for the experiment. They were tagged to identify them from each other and kept under intensive management for the experimental period. The initial body weight, heart girth and height at withers of the animals were recorded before the experiment started. The feeding exercise lasted for fifty six (56) days from February to April, 2017. Before the beginning of the feeding trial, all the animals were de-wormed with Albendazole 2.5\% suspension and Ivermectin 1\%injection against both endo and ecto parasites. The animals were then weighed at every week for the whole period of the experiment, to monitor changes in their growth.

All feed ingredients used as daily rations were divided into energy and protein sources. The energy source included Maize bran and Rice bran while the protein sources Cowpea haulms and Coconut meal, using the standard guide of 60:40, energy to protein ratio (Mohammed et al., 2007).

Treatment I was allowed to graze freely without the diets given to the animal; Treatment II was given the diets at every 7:00 am daily before going out to graze. While Treatment III was given the diets ad libitum with clean drinking water respectively.

\subsection{Experimental Design and Treatments}

The three (3) animals were assigned to the three treatments diets in three different trial of feeding in a Randomized Complete Block Design (RCBD) with one animal each treatment. The feed ingredients were obtained locally and fed the animals to examine their growth performances.

\begin{tabular}{|l|l|l|l|}
\hline \multicolumn{4}{|c|}{ TREATMENTS } \\
\hline FEEDS & T I & T II & T III \\
\hline & Grazing only & $150 \mathrm{~g}(\mathrm{RB})$ & $150 \mathrm{~g}(\mathrm{RB})$ \\
\hline & & $200 \mathrm{~g}(\mathrm{CM})$ & $200 \mathrm{~g}(\mathrm{CM})$ \\
\hline & & $100 \mathrm{~g}(\mathrm{CH})$ & $100 \mathrm{~g}(\mathrm{CH})$ \\
\hline & & $180 \mathrm{~g}(\mathrm{MB})$ & $180 \mathrm{~g}(\mathrm{MB})$ \\
\hline
\end{tabular}

Rice bran= $(\mathrm{RB})$, Coconut meal $=(\mathrm{CM})$, Cowpea haulms $=(\mathrm{CH})$, Maize bran $=(\mathrm{MB})$

\subsection{Data Collection}

Parameters measured were live weight changes and linear body measurements such as heart girth and height at withers.

Live weight gain: This was determined by the differences in weights of present and previous weeks.

Height at withers: This was determined by measuring the height of the animal from the hoof to the withers, the differences of the present and previous week were taken as the change in withers height. 
Change in girth: This was determined by the difference obtained from the previous week measurement and subsequent measurements of the animal's chest round the withers region. Group farmer's interview was also held to collate the views of the farmers on the adoption of the feeding program based on the performances of the animals.

\subsection{Data Analysis}

The data collected were subjected to simple comparisons of the performances of the animals.

\section{Results and Discussion}

\subsection{Proximate Composition of the Experimental Diets}

The results of the chemical composition of the experimental diets are shown on table one (1). Dry matter (DM) content for the protein supplements ranged from (92 and 93\%). The crude protein (CP) content of the coconut meal was high $(21.0 \%)$ while the lowest (12.97\%) was recorded for cowpea haulms. In both ingredients, the crude protein content is well above the normal range of about $7.7 \%$ which the critical value recommended for small ruminants (NRC, 1981) and higher than the minimum protein requirement of 10-12\% recommended by NRC (1981) for ruminants and it also agreed with the result obtained by Lukden and Finangwai, (2013). Ether extract (EE) obtained for coconut meal was high $(6.7 \%)$ and this could have been due to the efficiency of oil extraction. However, low value was recorded for cowpea haulms $(0.65 \%)$. The crude fiber (CF) content of cowpea haulms was much higher $(33.40 \%)$ than that of the coconut meal with (12.0\%). The values nitrogen free extract (NFE) of both coconut meal and cowpea haulms are the same with $(0.0 \%)$.

Similarly, the values of dry matter (DM) content for the energy supplements are the same with $(91.0 \%)$. The values of crude protein (CP) content for rice bran was high (14.0\%) and low in maize bran with (11.0\%). The values of ether extract (EE) for rice bran was high with $(17.0 \%)$ and low in maize bran with (13.0\%), consequently, the crude fiber (CF) content was also high in rice bran and low in maize bran with $(10.0 \%)$. The value of ash in rice bran was also high $(11.0 \%)$ and low in maize bran with $(3.0 \%)$, the nitrogen free extract (NFE) for rice bran was $(0.0 \%)$ and that for the maize bran was high with $(57.9 \%)$.

Table 1: Proximate composition of the experimental diets fed to goat

\begin{tabular}{|l|l|l|l|l|l|l|}
\hline \multicolumn{7}{|c|}{ Feed composition (\% DM) } \\
\hline Feed & DM & CP & EE & CF & ASH & NFE \\
\hline Protein Sources & \multicolumn{7}{|l|}{} \\
\hline Coconut meal & 92.0 & 21.0 & 12.0 & 6.7 & 7.0 & - \\
\hline Cowpea haulms & 93.0 & 12.97 & 0.65 & 33.40 & 7.14 & - \\
\hline Energy sources & 91.0 & 14.0 & 17.0 & 13.0 & 11 & - \\
\hline Rice bran & 91.0 & 11.0 & 6.3 & 10.0 & 3.0 & 57.9 \\
\hline Maize bran & 91.0 & & & & & \\
\hline
\end{tabular}

Source: Aduku A.O, (1993) and Feed Composition Table for Animal Required Nutrients/ Beef Magazine (2006). 


\subsection{Growth Performance}

Table 2 shows the summary of the characteristic performances of the animals fed with different sources of protein and energy sources. The dry matter intake was obtained high in treatment three (3) with (662.25g/day), indicating the animal fed intensively with the formulated diets. The lowest feed intake was obtained in treatment one (1) with $(580.02 \mathrm{~g} / \mathrm{day})$, indicating the goat fed on throughout grazing, this may occur as a result of in-proportional diets fed on the field. In the case of the animal on treatment two (2), the dry matter intake obtained was $641.00 \mathrm{~g} / \mathrm{day}$. Next to the animal fed intensively on treatment three (3) with the diet, which may occur due to the diet fed before grazing.

The weight gain of goats recorded in this research ranged from $82.50 \mathrm{~g}$ for goat in treatment one (1) to $115.25 \mathrm{~g}$ for goat on treatment three (3), that was fed intensively with the formulated feed. Therefore, from the result of this research, it is seen that proper formulation of crop residues (protein and energy sources) brings about an increase in the performances in animals, if well fed and managed intensively.

Table 2: The growth performance of the animals

\begin{tabular}{|l|l|l|l|l|}
\hline \multicolumn{2}{|l|}{ Parameters } & \multicolumn{2}{l|}{ Treatments } & LSD \\
\hline & T I & \multicolumn{2}{l|}{ T IIT III } & \\
\hline Initial live weigh (kg) & 16.83 & 17.33 & 17.70 & - \\
\hline Final live weight (kg) & 23.76 & 24.41 & 27.38 & 0.68 \\
\hline Daily weight gain (g/day) & 82.50 & 84.28 & 115.25 & $* 27.73$ \\
\hline Dry matter intake (g/day) & 580.02 & 641.00 & 662.52 & $* 46.09$ \\
\hline
\end{tabular}

$\mathbf{L S D}=$ Least significant difference. $\mathbf{N s}=$ Not significant $(>0.05) *$ Significant $(\mathrm{p}<0.05)$.

The group farmers interview was conducted and out of twenty seven (27) of the farmers, nineteen (19) of them were convinced with the research and have adopted the feeding formulation tried the fattening practices. The remaining eight (8) of the farmers have not been fully attending the experimental meeting, and so they have little ideas about research. Therefore, the utilization of Coconut meal, Maize bran, Rice bran and Cowpea haulms has a maximum effect on the growth performance of goats if adopted in the area.

\section{Conclusion and Recommendations}

From the result the study, it is realized and concluded that proper formulation agricultural byproducts rank high in feed intake and daily weight gain of animals. However, since the agricultural by-products are cheaply found in the area, farmers should learn from this study on how to manage and utilize their agricultural by-products especially during the harvesting period. Therefore, the utilization of Coconut meal, Maize bran, Rice bran and Cowpea haulms as energy and protein sources obtains good performances in fattening of goats without deleterious effects on the growth.

There is the need for sponsoring the extension agents by the Government and non-Governmental Organization (NGOs) to extend new ideas to the farmers on different fields of agriculture in order to boost and improve both crops and animal production in the area. Farmers should be given intensive training on ideas of feed formulation and management practices of keeping animals. 
Other agricultural by-products should be investigated through laboratory analysis to help improve performances of livestock production in the area. Sources of drinking water have been pending problems in the area. Therefore, Government should provide them with portable drinking to reduce the difficulty of their fattening practices. Grazing land is another issue of rearing of the animals, especially for the young and milking mother's which is allowed for grazing in order to economize the use of the stored feeds which are used for fattening. Therefore, Government should be addressed about the issue. Storage facilities should be provided by Government to improve the shelf of the feeds gathered for use during the scarcity period.

\section{References}

[1] Aduku, A.O. (1993). Tropical Feed stuff Analysis Table, Department of Animal Science, Faculty of Agriculture, Ahmadu Bello University, Samaru-Zaria, Nigeria.

[2] Ayatunde A. A, Fernandez-Rivera S., and Dan-Gomma A (2008). Sheep fattening with Groundnut haulms and millet bran in the West African Sahel. Sheep fattening - Crop residue- Animal nutrition- Animal production- Mixed farming- Sahel- Niger. International Journal of Innovative Research and Development.

[3] Ayoola, G.B. and Ayoade, J.A. (2006). Socio-economic and policy aspects of using Residues and Agro-industrial by-products as alternative livestock feed Resource in Nigeria. International Journal of Innovative Research and Development.

[4] Bamikole M. A., Ikhatua U. J, Arigbede O. M., Babayemi O. J., Etela I., (2004). An evaluation of the acceptability as forage of some nutritive and anti-nutritive components and of the dry matter degradation profiles of five species of ficus. Tropical Animal Health and production, 36:157-167.

[5] Borogo S. Niba AT \& Butswat ISR (1999). Goats: The threatened species In our backyards: proceedings of an international seminar promoting sustainable small-scale livestock production towards reduction of malnutrition and poverty in rural and sub-urban families in Nigeria. ATBU Bauchi. Pp 56-61

[6] Devendra C (1997). Mixed farming and intensification of animal production system in Asia. Outlook on Agriculture, 26(4): 255-265.

[7] Dhanda JS, Taylor DG, Murray PJ, Pegg RB \& Shand PJ (2003). Goat meat production: Present Status and future possibilities. Asian-Australian journal of Animal Science, 16 (12): 1842-1852.

[8] Dubeuf, J.P., Monrand-Fehr, P. and Rubino., (2004). Situation Changes and Future of Goat Industry around the World. Small Ruminant Research. 51, 165-173.

[9] Fanatico, M. A., Morrow, R., and Wells, A. (1999). Sustainable production. NCAT publication http/www.att.or/attar-pub/PDF/sust beef-paf, pp.1-15.

[10] FAO (2010). Food and Agricultural Organization. Food and Agricultural Organization of the United Nations, Rome, Italy.

[11] FAO (1981). Production Year Book. Vol.34

[12] FAO (1982). Production Year Book. Vol.35. Rome, Italy.

[13] FAO, (1985): Better utilization of crop residues and by-products in animal feeding.

[14] Research guidelines. Animal Production and Health Paper. No. 50

[15] FAO, Rome, Italy, Pg.213.

[16] FAO STAT, (2009). Food and Agricultural Organization Statistical Data Base.

[17] Feed Composition Table for Animal Required Nutrients/Beef Magazine, (2006).

[18] Finangwai, H.I., Ehoche, O.W and Akpu, G.N. (2010). Effect of Urea Treated Maize Stover Based Complete Diet on the Biochemical Changes in the Rumen and Blood Parameters of Cross Bred Bull. Proc. Conference 13-15th September, University of Uyo, Nigeria. Pp 609.

[19] Galal, S., (2005). Biodiversity in Goats. Small Ruminant Research. 60, 75-81.

[20] Gimenez, M. D., (1994). Nutrient Requirements of Sheep and Goats. The Alabama 
[21] Cooperative Extension System (AlabamaA and $M$ University and Album University). http://www.aces.edu/pubs/docs/A/ANR-0812pdf.

[22] Hirpa, A. and Abbe, G. (2008). Economic Importance of Sheep and Goats. In Sheep and Goats Production Handbook for Ethiopia, Addis Ababa. Pp.1-4

[23] Jarasuriya, M.C.N (1985): Potential for better utilization of Crop residues and Agro-industrial byproducts in animal feeding in the Indian sub-continent. In: Better utilization of crop residues and by-products in animal feeding. FAO) Rome, Italy, 1: Pp 37-49.

[24] Jean, P. (1993). "Animal production in the tropics and sub-tropics". First edition, Macmillan press Ltd., London.

[25] Jimjel Z., Daniel J. D and Hyelkaya P. (2013). Technical efficiency Sheep fattening In Gombi area of Adamawa State, International journal of innovative Research and Development.

[26] Khan, B.B. (2003). Sheep and Goats production, University of Agriculture Faisalabad. Pp1617, 54.http://dvmdocs.web.com/LM\%20Mannuals/Sheep goats 1. Pdf Retrieved on 14/11/2011.

[27] Lebbie S.H.B (2004). Goats under household conditions. Small Ruminant Research. 51(2): 131136.

[28] Lemus, R. and Brown, K. (2008). Feeding Small Ruminant Developing Grazing System for Sheep and Goats. Cooperative Extension Service Mississippi State University. Pp. 4. Retrieved on $14 / 11 / 2011$

[29] Luginbuhl, J.M and Poore, M.H. (1998). Nutrition of Meat Goats. http://www. Cals.nesu.edu/anSci/extension/animal/ahgoats.htm. Recovered Energy. Small Ruminant Research. 53, 221-230.

[30] Mahanjana AM \& Cronje BP (2000). Factors affecting goats production in a communal farming system in the Eastern Capergion of South Africa. South African Journal of Animal Science, 30 (2): 149-154.

[31] Makun H.J, Ajanusi J.O, Edoche O.W, Olorunju S.A.S \& Otaru S.M (2005). Ownership patterns of goat milking practices in Nigeria. Savanna. Ahamadu Bello University, 20(1): 17-29.

[32] Malau-Aduli, B. S., Eduvie, L., Lakpini, C. and Malau-Aduli, A. E. O. (2003). Chemical compositions, feed intakes and digestibility's of crop residues- based rations in non lactating Red Sokoto goats in sub-humid zone of Nigeria. Animal Science Journal, 74(2), 89-94.

[33] Mbahi, T. F., Kibon, A., Yahaya, M. S. and Gworgwor, Z. A. (2006). Effects of lablab hayand groundnut haulms supplementation on intake and degradability of sorghum Stover by Sheep. Nigerian Journal of Tropical Agriculture, 8, 136-140.

[34] McDonald, P., Edwards, R. A. and Greenhalgh, J.F. (1995). Animal nutrition (5th edition). Longman Group (UK) LTD, Essex, UK. Pp482-488.

[35] Merck, S. and Dhome, C. (2011). The Merck Veterinary Manual, 10th Edition, Whitehouse Station, N.J USA. http://www.merckvetmanual.com/mvm/indexjsp?cfile=htm/bc/182502.htm Retrieved on $25 / 11 / 2011$.

[36] Mohammed, I.D, Baulube M and Adeyinka I.A (2007). Multi-nutrient block1: formulation and production under a semi-arid environment of Northeast Nigeria. Journal of Biological Science, 8(2), 389-392.

[37] Morris, S. T., (2006). Feed Conversion Efficiency in Beef Production Systems. Nutritional Management of Pastoral Animal Production and Health Institute of Veterinary, Animal and Biomedical Science Massey University. http://ivabs.massey.ac.nz/feedconveff.asp.htm. Retrieved $14 / 11 / 2011$

[38] Neuman, L. (1977). Beef Cattle. Seventh edition, John Wiley and sons inc. New York, USA, Pp. 8-11.

[39] NRC, (1981). Nutrient Requirements of Goats: Angora, Dairy and Meat Goats in Temperate and Tropical Countries. National Academies Press, Washington, D.C 2001.

[40] NRC, (2011), Nutrient Requirements of Small Ruminants: Sheep Goats, Cervids, and NewWorld Camelidthe National Academies Press, Washington, D.C 20001

[41] Olivier, J.J., Cloete, S.W.P., Schoeman, S. J. and Muller, C. J. C., (2005PerformanceTesting and Recording in Meat and Dairy Goats. Small Ruminant Research, 60, 83-93. 
[42] Okunlola, O.O., Amuda, A. J. and Ayanwamide, F. M., (2010). Farmers Perception of Livestock Farming in Oyo State: A Case Study of Small Ruminant Farmers. Proc. 35th Conf., Nigeria Society for Animal Production. 14-17 March, University of Ibadan, Nigeria.

[43] Ozung, P. O., Nsal, E. E., Ebegbulem, V. N. L. and Ubua, J. A. the potentials of small ruminant production in Cross River Rain Forest Zone of Nigeria: A Rebview, Continental Journal of Animal and Veterinary Research 3 (1): 33-37. http:/www.wiloludjournal.com.Retrieved on 16/07/2009.

[44] Osuhur, C. U., Alawa J. P. and Akpa, G.N. (2002). Manure Production by Goats Grazing Native Pasture in Nigeria. Tropical Grasslands (2002) Volume 36, 123-125.

[45] Osuhur, C. U., and Olatoye, O. (2010). Goat Farming, 2004-2011. African Newspaper of Nigeria plc. http:/ww.tribune.com.ng/index/php/wealth- creation-thru-agric/1923-goat-farming 1. Retrieved on 12/12/2011.

[46] Osuji, P. O, Nsahlai, I. V., and Khalili, H. (1993). "Feed Evaluation" ILCA Manual 5, International Livestock Center for Africa, Addis Ababa, Ethiopia, 40p.

[47] Ozung, P. O. Nsa, E. E., Ebegbulem, V. N. and Ubua, J. A. (2011). The Potentials of Small Ruminant Production in Cross River Rain Forest Zone of Nigeria: A Review, Continental Journal of Animal and Veterinary Research 3 (1): 33-37, 2011.http:/www.wiloludjournal.com.Retrieved on $14 / 11 / 2011$.

[48] Pennstate, (2000). Agriculture alternatives: Meat goat production, http://agalternatives.aers.psu.edu/livestock/meatgoat.pdf Retrieved on 16/11/2011

[49] Raddish, P.M. and Scarr, M.J. (1987): Subsiding industries for the livestock subsector Proc.11thConf. Nigerian Soc. Prod. Zaria pp. 12-23.

[50] Reddy, D. V. (2007). Applied Nutrition: livestock, Poultry, Pet, Rabbit and Laboratory Animal Nutrition. Oxford and IBH publishing CO. PVT LTD, New Delhi. Pp 127.

[51] Rim, (1993). Resource Inventory Management System Limited, Federal Department of Livestock and Pest Control service Abuja. Section III-2.1: Small Ruminant Goats. Pp. 150-160.

[52] Savadogo M, Zemmelink G, Nianogo A J and Van Keulen H (2000).Cowpea Vignaunguiculata L. Walpand groundnut Arachys hypogeal L. haulms as supplements to sorghum, Sorghum bicolor L. Moenchstover: intake, digestibility and optimum feeding levels. Animal Feed Science and Technology 87, 57-69.

[53] Schoenian, S. (2009). An Introduction to Feeding Small Ruminants. http://www.Sheepandgoat.com/articles.html.Retrieved on 13/12/2011

[54] Simela, L. and Merkel, R., (2008). The Contribution of Chevon Africa to Global Meat Production. Meat Science, 80: 101-109.

[55] Smith, O. B., Idowu, O. A., Asaolu, V. O and Odunlami, O. (1991). Comparative rumen degradability of forages browse, crop residues and agricultural by-products. Livestock Research for Rural Development, 3 (2), 1-7.

[56] Solaiman, S. G (2007). Assessment of the Meat Goat Industry and Future Outlook for USA Small Farms.http://www.agmre.og/media/ems/ USGoatProductionFinal-E1367962C32D1.pdf. Retrieved on $14 / 11 / 2011$.

[57] Steele, M. (1996). Goats: The Tropical Agriculturalist. Macmillan Education Limited London and Basing Stoke. Pp 9-21.

[58] Thompson, D., (2006).Meat Goat Breeds Breeding Managementand4-H Market Goat Management. http://www.extension.umn.edu/meatgoats/co.mponents. Retrieved on 14/11/2011

[59] Uza, D. V. (1998). Cattle and Small Ruminants Fattening Module for the family Economic advancement Programme: In Animal Agriculture in West Africa. Inaugural Conference 21st-26th March, 1998, University of Agriculture, Abeokuta, Nigeria. 186-206.

[60] Win rock International (1983). Sheep and Goats in Developing Countries: Their Present and Potential Role. A World Bank Technical Paper, Win rock Int Morrilton, Arkansas, U.S.A 721109537. 
[61] Yashim, S. M. and Jokthan, G. E. (2010). Effect of Different Parts of Plant on the Nutritive Value of Rattle Box (Crotalaria retusal) Plant. Proceedings of 15th Conference ASAN, 13-15 September, 2010, University of Uyo Nigeria. Pp.677

\footnotetext{
*Corresponding author.

E-mail address: abdualiyu14@ymail.com
} 